\title{
Costs and Profitability of Urdbean on Sample farms
}

\author{
Ghanshyam Patel", A. Shrivastava and Reena Sahu \\ Department of Agricultural Economics and Farm Management, \\ JNKVV, Jabalpur, M.P., India \\ *Corresponding author
}

Keywords

Urdbean,

Costs and

Profitability

\section{Article Info}

Accepted:

22 December 2019

Available Online:

20 January 2020
A B S T R A C T

Urdbean or black gram is one of the most important cultivated pulse crops of the 'Vigna' group. Seeing to the importance as a major pulse crop a research study was carried out on sample farms to work out the costs and profitability of urdbean. A multi-stage random sampling technique was adopted for data collection; the study was conducted in Lailunga block of Raigarh district (C.G.), sample of 3 villages of this block was selected randomly. A sample of 60 farmers in the ratio of 20:20:20 was selected randomly. The farmers were classified into three groups viz., small $(<2.00$ hectares), medium (up to $2.00-4.00$ hectares) and large $(>4.0$ hectares) farms. It was found that overall cropping pattern in study area was dominated by paddy followed by urdbean, the employment of family labour showed reverse relation with the size of farm. The operational cost were comparatively higher in large size farm, the productivity of urdbean was higher in small size group. The net return over cost $\mathrm{C}_{3}$ was (total cost) observed higher in large size farm. It was also observe the Family labour income was higher in small size group which tends to decline as per increase of farm size. The net return per farm was higher in small size group due to higher allocation of urdbean area.

\section{Introduction}

India is the largest producer of pulses in the world, both in terms of quantity and variety. Once a net exporter, turned into one of the largest importer of pulses. Pulses are the primary source of protein for the poor and the vegetarians who constitute the majority of Indian population and the traditional cropping pattern invariably included a pulse crop either as a mixed crop or in rotation. The commercialization of agriculture has encouraged the practice of sole-cropping. Pulses are least preferred by farmers because of high risk and less remunerative than cereals; consequently, the production of the pulses is sufficiently low. To meet the demand of pulses, India is at present importing about 3 million tons of variety of pulses [1]. 
Pulses are one of the important segments of Indian Agriculture after cereals and oilseeds. These pulses comprise chickpea, pigeon pea, lentil, mungbean, urdbean and field pea. The split grains of these pulses called 'dal' are excellent source of high quality protein, essential amino and fatty acids, fibers, minerals and vitamins. These crops improve soil health by enriching nitrogen status, longterm fertility and sustainability of the cropping system. It meets up to 80 per cent of its nitrogen requirement from symbiotic nitrogen fixation from air and leaves behind substantial amount of residual nitrogen and organic matter for subsequent crops. The water requirement of pulses is about one-fifth of the requirement of cereals thus effectively save available precious irrigation water [2].

Major portion of urdbean is utilized in making dal, for curries, soup, sweets and snacks. In South India, the most popular Idli and dosa are prepared using mixed proportions of rice and urdbean. The food values of urdbean lie in its high and easily digestible protein. Urdbean seeds are known to contain high protein $(25-28 \%)$, oil (1.0 $1.5 \%)$, fiber $(3.5-4.5 \%)$, ash $(4.5-5.5 \%)$ and carbohydrates $(62-65 \%)$ on dry weight basis. Amino acid analysis indicates that as with most grain legume crops, the concentrations of sulphur containing amino acid (methionine and cystine) are small [3].

Chhattisgarh state comprising 27 districts, having 342.56 thousand hectare of area under pulses with 145.54 thousand metric tons of production. Chhattisgarh is a predominantly a tribal and rice growing region its constituent agro climatic zones are Chhattisgarh plain, Bastar plateau, and Northern hills with 27 districts. Being predominantly tribal, the major source of diet basket is rice which is also a staple food for majority of the people. The urdbean, mungbean and arhar has been drawing continuous attention of government agencies to improve the scenario of pulse production so as to address the growing demand of pulses in the state and to counter the rising prices of pulse witnessed in the recent past.

Looking to the growing importance of pulses in daily diet and agrarian economy the research study was taken up to work out the costs and profitability of urdbean on sample farms [4].

\section{Materials and Methods}

This study was undertaken to work out the cost and return incurred in urdbean production in Raigarh district. This deals with the nature and type of data required, sampling techniques used for collecting the data and the analytical tools applied in processing of the data for their economic interpretation. It also includes the general description of the study area, concepts and terms used in the study etc.

The research design of study has been considered in the following heads:

1. Sampling technique

2. Selection of district

3. Selection of block

4. Selection of village

5. Selection of respondents

6. Nature and source of data

7. Period of study

8. Analysis of data

\section{Sampling technique}

Lailunga block of Raigarh district was purposively chosen as the study area as, it has the larger area under urdbean in the district. A multistage stratified random sampling technique was adopted to select the district, block, villages and the respondents engaged in urdbean production in Raigarh district. 


\section{Selection of district}

It the First stage sampling, Raigarh district was selected purposively as this district was having the highest area under urdbean crop in the state ie. 18.18 per cent of the total urdbean area of the state.

\section{Selection of block}

It the Second stage, out of nine blocks of the raigarh district namely, Baramkela, Gharghoda, Lailunga, Raigarh, Tamnar, Dharamjaigarh, Kharsia, Pussore and Sarangarh, Lailunga block was selected for the study as it has maximum area (4,377 ha.) under urdbean within Raigarh district.

\section{Selection of the villages}

It the Third stage, after selection of block, List of urdbean growing villages was prepared. From the list of villages, 3 villages Lailunga, Tolma and Gahna jhharia were selected purposively.

\section{Selection of respondents}

Finally after selection of villages, at fourth stages, a list of urdbean growers was prepared and further categorized in to three size of group on the basis of size of land holding, i.e. small farmer (upto $2.0 \mathrm{ha}$ ), medium farmer (>2 to 4 ha) and large farmer (above 4 ha). From each size group 20 farmers were selected randomly thus, total 60 farmers were considered for detail investigation to fulfill the stated objectives from the total 257 urdbean farmers. The primary data on the relevant, aspects specified in objectives were collected from the sample farmers for the reference year 2016-17 survey.

\section{Nature and source of data}

The data required for the present investigation were primary and secondary both in nature. The primary data were collected from the samples through survey method and the secondary data were collected from various official publication of Raigarh and department of Agricultural Chhattisgarh. Primary data were collected from selected farmers of urdbean.

\section{Period of study}

The study period pertains to the agricultural year 2015-16.

\section{Analysis of data}

\section{Cost items}

The items of cost of cultivation cover both paid out cost (out of pocket expenses cash + kind) and the imputed costs. The items covered under these costs areZ

Paid - out costs

Hired labour (human, animal and machinery). Maintenance expenses on owned animals and machinery.

Expenses on material inputs such as seed (home grown and purchased), fertilizer, manure (owned and purchased) and pesticides.

Depreciation on implements and farm buildings.(such as cattle sheds machine sheds, storage sheds).

Land revenue.

Rent paid for leased in land.

\section{Imputed costs}

Include the value of family labour /managerial input of the farmer, rent of owned land and interest on owned fixed capital for which the farmer does not incurred any cash expenses. 


\section{Total cost}

The sum of fixed and variable costs make total cost for producing per hectare crop or per unit/number of livestock.

\section{Cost of cultivation (Rs./ha)}

Operational cost - It is the expenses related to the costs of running business operations. These are two types fixed costs and variable costs.

Fixed costs: These costs are related to fixed resources and overhead costs. Rent, interest, depreciation, taxes and wages of the permanent labour constitute fixed costs.

Variable costs: These costs are related to the variable resources and changes with the level of output.

Cost of production $(\mathrm{Rs} / \mathrm{q})=$

$$
\frac{\text { Total cost }- \text { value of by product }}{\text { Yield }}
$$

\section{Cost concepts}

Cost $\mathbf{A}_{\mathbf{1}} \quad$ : $\quad$ All actual expenses in cash and kind incurred in production by owner operator.

Cost $\mathbf{A}_{2} \quad$ : $\quad$ Cost $\mathrm{A}_{1}+$ rent paid for leased in land.

Cost $\mathrm{B}_{1} \quad$ : $\quad$ Cost $\mathrm{A}_{2}+$ interest on value of owned fixed capital assets (excluding land).

Cost $\mathbf{B}_{2} \quad$ : $\quad$ Cost $\mathrm{B}_{1}+$ rental value of owned land.

Cost $\mathbf{C}_{1} \quad$ : $\quad$ Cost $\mathrm{B}_{1}+$ imputed value of family labour.
Cost $\mathbf{C}_{2} \quad$ : $\quad$ Cost $\mathrm{B}_{2}+$ imputed value of family labour.

Cost $\mathbf{C}_{3} \quad$ : $\quad$ Cost $\mathrm{C}_{2}+10$ percent of $\operatorname{cost} C_{2}$ to account for Managerial input of the farmer.

\section{Profitability concept}

\section{Total production}

Total quantity of output produced by a firm for given quantity of inputs.

Total production $=$ Main product + by product

\section{Gross income}

It is the total value of main product and value of by product.

Gross Income $=$ Value of main product + Value of by product

\section{Farm business income}

It is the gross income minus total expenses of production excluding wages of family labour, interest on owned and rental value of land. It is measure of the earning of a farmer and his family for their capital investment, labour and managerial work.

It can be expressed as:

$\mathrm{FBI}=$ Gross income - Cost $\mathrm{A}_{1}$

\section{Family labour income}

It includes net income or loss plus imputed value of wages for the labour of farmer and his family.

$\mathrm{FLI}=$ Gross income - Cost $\mathrm{B}_{2}$ 


\section{Net income}

It is net profit after deduction of all cost items, variable and fixed gross income

Net Income $=$ Gross Income - Total Cost

\section{Cost of production (Rs/q)}

The expenditure incurred in producing a unit quantity of output is called cost of production.

Cost of production $(\mathrm{Rs} / \mathrm{q})=$

$$
\frac{\text { Total cost }- \text { value of by product }}{\text { Yield }}
$$

\section{Average variable cost}

It is the amount spent on the variable inputs to produce a unit of output.

Average variable cost $=$

\begin{tabular}{c} 
Total Variable cost \\
\hline Yield
\end{tabular}

Average fixed cost: It is the cost of fixed resources or inputs required for producing one unit of output and it is given by the formula as

Average fixed cost $=$

\section{Total fixed cost}

Yield

\section{Benefit cost ratio}

B.C.R. =

Gross income

Total cost

\section{Results and Discussion}

Finally, the primary data collected for study has been analysed and the results of the study were presented below:

\section{Cost of cultivation of urdbean production}

The average per hectare cost of cultivation was worked out at Rs. 27562.38. Among the various costs, rental value of the land was costliest input and accounted for more than 27 per cent for different size group this ranged between highest $(31.14 \%)$ in small farms and lowest $(25.82 \%)$ in large size farms. Fertilizer was the other important input which accounted for 17.48 per cent of the total cost. Among different size groups again, small size farms reported highest proportion of fertilizer /manure cost $(19.59 \%)$ followed by medium $(18.54 \%)$ and large size farms $(14.72 \%)$. Seed contributed little to the total cost and it shared 3.31 per cent to the total cost incurred. The lower proportion of seed cost was minimum due to the fact that farmers used their owned seed rather than costly seed of compares. It can be seen for the table that the hired human labour cost in the form of wages was substantially higher in large size farm and ranged between Rs. 3270.48 (maximum) and Rs. 1700.65 in small size (minimum). The medium size farmers reported Rs. 3,070.87 as hired human labour cost.

\section{Cost of cultivation of urdbean}

The operational cost known as cost $\mathrm{A}_{1}$ accounted for Rs. 11,562.48 in small size followed by Rs. 14,448.62 in medium size and Rs. 15,233.52 in large farm size. Cost $\mathrm{A}_{2}$ accounted for Rs. 11,584.48 in small size followed by Rs.14, 470.62 in medium size and Rs. 15,255.52 in large farm size. Cost $B_{1}$ a sum of cost $A_{1}$ and interest on fixed capital amounted for Rs. 3,111.32 in small size, Rs. 4,253.25 in medium and Rs. 5,846.24 in large size group. 
Table.1 List of selected respondent of Lailunga Block

\begin{tabular}{|c|l|c|c|}
\hline S.No. & Particular & Number of farmers & Farmers selected \\
\hline 1. & Small & 112 & 20 \\
\hline 2. & Medium & 66 & 20 \\
\hline 3. & Large & 79 & 20 \\
\hline Total & & 257 & 60 \\
\hline
\end{tabular}

Table.2 Cost of cultivation of urdbean under different size of sample respondent (Rs/ha)

\begin{tabular}{|c|c|c|c|c|c|}
\hline S. No. & Cost item & Small & Medium & Large & Average \\
\hline $\mathbf{a}$ & \multicolumn{5}{|c|}{ Labour cost } \\
\hline 1 & Value of family labour & $\begin{array}{l}2540.25 \\
(10.14)\end{array}$ & $\begin{array}{l}1515.65 \\
(5.45)\end{array}$ & $\begin{array}{c}1039.81 \\
(3.48)\end{array}$ & $\begin{array}{l}1698.57 \\
(6.16)\end{array}$ \\
\hline 2 & Value of hired labour & $\begin{array}{l}1700.65 \\
(6.76)\end{array}$ & $\begin{array}{l}3070.87 \\
(11.04)\end{array}$ & $\begin{array}{l}3270.48 \\
(10.95)\end{array}$ & $\begin{array}{l}2680.66 \\
(9.72)\end{array}$ \\
\hline 3 & Value of Bullock labour & $\begin{array}{c}2329.13 \\
(9.30)\end{array}$ & $\begin{array}{c}1353.02 \\
(4.86)\end{array}$ & $\begin{array}{l}0 \\
--\end{array}$ & $\begin{array}{l}1227.38 \\
(4.45)\end{array}$ \\
\hline 4 & $\begin{array}{l}\text { Value of machine } \\
\text { operation }\end{array}$ & $\begin{array}{l}00 \\
---\end{array}$ & $\begin{array}{c}2012.36 \\
(7.23)\end{array}$ & $\begin{array}{l}4444.87 \\
(14.88)\end{array}$ & $\begin{array}{c}2152.41 \\
(7.80)\end{array}$ \\
\hline & Total & $\begin{array}{l}6569.13 \\
(26.24)\end{array}$ & $\begin{array}{l}7951.92 \\
(28.60)\end{array}$ & $\begin{array}{l}7951.92 \\
(26.63)\end{array}$ & $\begin{array}{l}7490.99 \\
(27.17)\end{array}$ \\
\hline b & \multicolumn{5}{|c|}{ Material Cost } \\
\hline 1 & Value of Seeds & $\begin{array}{l}957.73 \\
(3.82)\end{array}$ & $\begin{array}{l}885.98 \\
(3.18)\end{array}$ & $\begin{array}{l}896.43 \\
(3.00)\end{array}$ & $\begin{array}{l}913.38 \\
(3.31)\end{array}$ \\
\hline 2 & $\begin{array}{l}\text { Value of fertilizer \& } \\
\text { manure }\end{array}$ & $\begin{array}{l}4904.67 \\
(19.59)\end{array}$ & $\begin{array}{l}5155.63 \\
(18.54)\end{array}$ & $\begin{array}{r}4397.01 \\
(14.72)\end{array}$ & $\begin{array}{l}4819.10 \\
(17.48)\end{array}$ \\
\hline 3 & Value of Plant protection & $\begin{array}{l}526.07 \\
(2.10)\end{array}$ & $\begin{array}{l}542.58 \\
(1.95)\end{array}$ & $\begin{array}{r}698.69 \\
(2.34)\end{array}$ & $\begin{array}{l}589.11 \\
(2.13)\end{array}$ \\
\hline 4 & $\begin{array}{c}\text { Interest on working } \\
\text { capital (@ 4\%) }\end{array}$ & $255.53(1.02)$ & $\begin{array}{l}263.36 \\
(0.94)\end{array}$ & $\begin{array}{l}239.68 \\
(0.80)\end{array}$ & $\begin{array}{r}252.85 \\
(0.91)\end{array}$ \\
\hline & Total & $6644(26.54)$ & $\begin{array}{c}\mathbf{6 8 4 7 . 5 5} \\
(24.62)\end{array}$ & $\begin{array}{l}\mathbf{6 2 3 1 . 8 1} \\
(\mathbf{2 0 . 8 7 )}\end{array}$ & $\begin{array}{l}\mathbf{6 5 7 4 . 4 5} \\
(23.85)\end{array}$ \\
\hline c & \multicolumn{5}{|c|}{ Fixed cost } \\
\hline 1 & Taxes, land revenue & $22(0.08)$ & $22(0.07)$ & $22(0.07)$ & $22(0.07)$ \\
\hline 2 & Depreciation & $\begin{array}{l}889.6 \\
(3.55)\end{array}$ & $\begin{array}{l}1164.8 \\
(4.18)\end{array}$ & $\begin{array}{l}2089.6 \\
(6.99)\end{array}$ & $\begin{array}{c}1381.33 \\
(5.01)\end{array}$ \\
\hline 3 & $\begin{array}{l}\text { Rental value of own land } \\
\text { (1/6 of Gross Income) }\end{array}$ & $\begin{array}{l}7796.76 \\
(31.14)\end{array}$ & $\begin{array}{l}7562.70 \\
(27.20)\end{array}$ & $\begin{array}{l}7710.56 \\
(25.82)\end{array}$ & $\begin{array}{l}7690.00 \\
(27.90)\end{array}$ \\
\hline \multirow[t]{2}{*}{4} & $\begin{array}{c}\text { Interest on fixed capital } \\
\quad(@ 10 \%)\end{array}$ & $\begin{array}{l}3111.32 \\
(12.42)\end{array}$ & $\begin{array}{l}4253.25 \\
(15.29)\end{array}$ & $\begin{array}{l}5846.24 \\
(19.58)\end{array}$ & $\begin{array}{l}4403.60 \\
(15.97)\end{array}$ \\
\hline & Sub total & $\begin{array}{c}11819.68 \\
(47.21)\end{array}$ & $\begin{array}{c}13002.75 \\
(46.76)\end{array}$ & $\begin{array}{l}15668.4 \\
(52.48)\end{array}$ & $13496.64(48.96)$ \\
\hline \multicolumn{2}{|r|}{ Total } & $\begin{array}{c}25032.81 \\
(100)\end{array}$ & $\begin{array}{l}27802.22 \\
(100)\end{array}$ & $\begin{array}{c}29852.13 \\
(100)\end{array}$ & $27562.38(100)$ \\
\hline
\end{tabular}

(Figures in parentheses indicate percentage to total) 
Table.3 Cost of Cultivation of urdbean crop under different size groups (Rs/ha)

\begin{tabular}{|l|c|c|c|c|c|}
\hline \multirow{2}{*}{ S.No. } & \multirow{2}{*}{ Cost } & \multicolumn{4}{|c|}{ Size group } \\
\cline { 3 - 6 } & & Small & Medium & Large & Average \\
\hline 1 & Cost $\mathrm{A}_{1}$ & 11562.48 & 14448.62 & 15233.52 & 13748.20 \\
\hline 2 & Cost $\mathrm{A}_{2}$ & 11584.48 & 14470.62 & 15255.52 & 13770.20 \\
\hline 3 & Cost $\mathrm{B}_{1}$ & 14695.8 & 18723.87 & 21101.76 & 18173.81 \\
\hline 4 & Cost $\mathrm{B}_{2}$ & 22492.56 & 26286.57 & 28812.32 & 25863.81 \\
\hline 5 & Cost $\mathrm{C}_{1}$ & 17236.05 & 20239.52 & 22141.57 & 19872.38 \\
\hline 6 & Cost $\mathrm{C}_{2}$ & 25032.81 & 27802.22 & 29852.13 & 27562.38 \\
\hline 7 & Cost $\mathrm{C}_{3}$ & 27536.09 & 30582.44 & 32837.34 & 30318.61 \\
\hline
\end{tabular}

Table.4 Profitability of urdbean crop under different size groups (Rs/ha)

\begin{tabular}{|c|c|c|c|c|c|}
\hline \multirow{2}{*}{ S.No. } & Particulars & \multicolumn{4}{|c|}{ Size group } \\
\cline { 3 - 5 } & & Small & Medium & Large & Average \\
\hline 1. & Production (q/ha) & 7.54 & 7.09 & 7.22 & 7.28 \\
\hline 2. & Production per farm & 4.19 & 5.16 & 9.50 & 6.28 \\
\hline 3. & $\begin{array}{c}\text { Cost of production per } \\
\text { quintal (Rs/Q) }\end{array}$ & 3320 & 3921.32 & 4134.64 & 3786 \\
\hline 4. & Price of per quintal & 6200 & 6400 & 6400 & 6333.33 \\
\hline 5. & Total cost (Rs) & 25032.81 & 27802.22 & 29852.13 & 27562.38 \\
\hline 6. & Gross Income (Rs) & 46780.57 & 45376.23 & 46263.39 & 46140.06 \\
\hline 7. & Farm business income(Rs) & 35218.09 & 30927.61 & 31029.87 & 32391.86 \\
\hline 8. & Family labour income(Rs) & 24288 & 19089.66 & 17451 & 20276.25 \\
\hline 9. & Net income(Rs) & 21747.76 & 17574.01 & 16411.26 & 18577.68 \\
\hline 10. & Benefit cost ratio at cost $\mathrm{C}_{3}$ & $1: 1.86$ & $1: 1.63$ & $1: 1.54$ & $1: 1.67$ \\
\hline
\end{tabular}

Fig.1 Cost of production, price of per quintal, total cost and gross income for different size group of farms

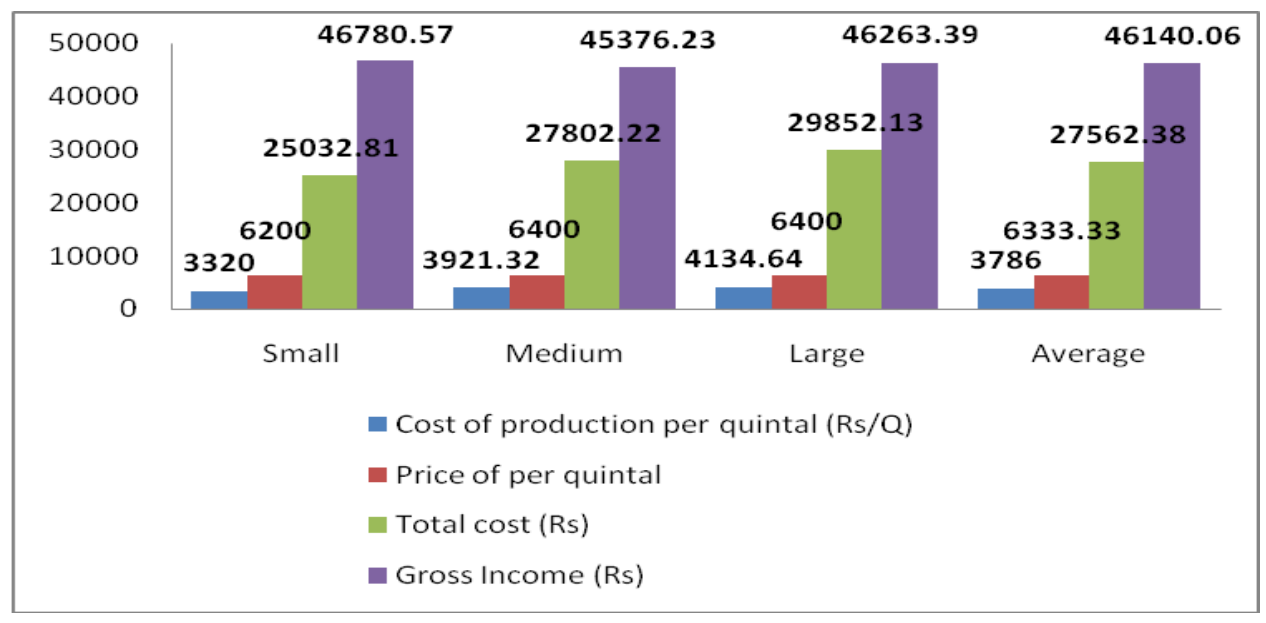


Fig.2 Farm business income, family labour income and net income for different size group of farms

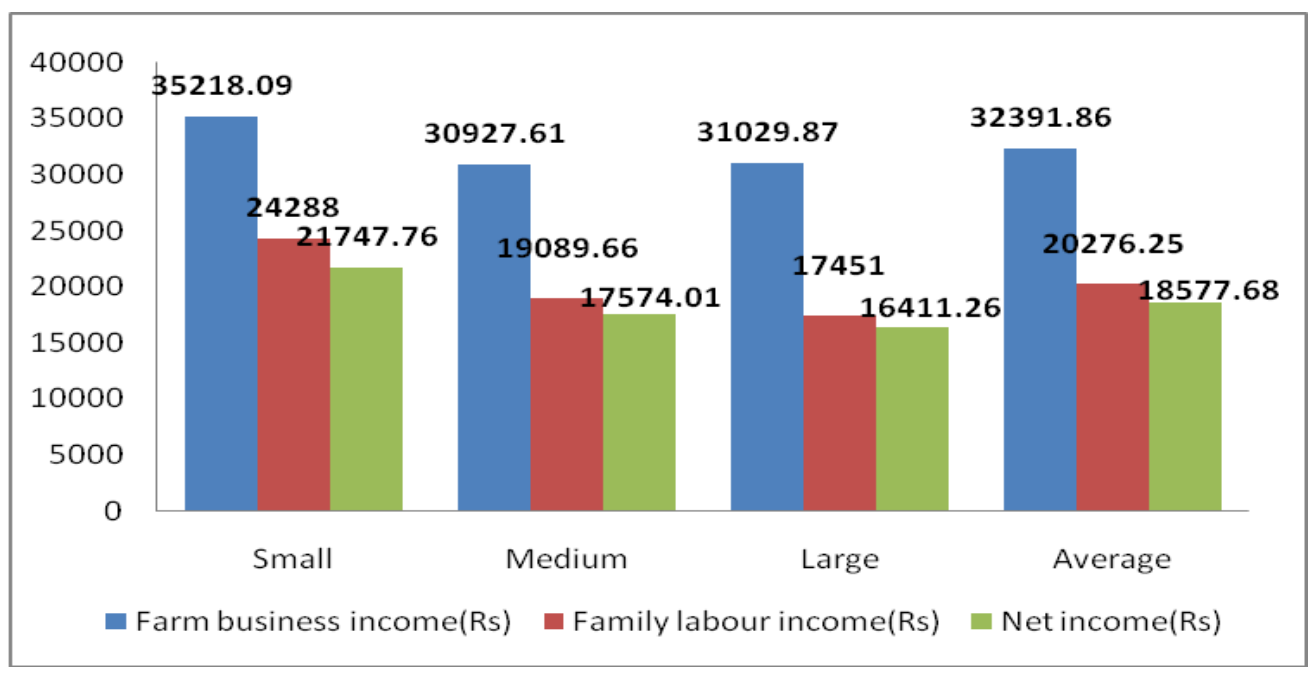

Fig.3 Benefit cost ratio for different size group of farms



Cost $\mathrm{B}_{2}$ a sum of cost $\mathrm{B}_{1}$ and rental value of own land amounted for Rs. 7,796.76 in small size, Rs. 7,562.70 in medium and Rs. $7,710.56$ in large size group. The cost $\mathrm{C}_{1}$ and $\mathrm{C}_{2}$ was found maximum in large size farm (Rs. 22,141.57 and Rs. 29,852.13) and minimum in small size (Rs. 17,236.05 and Rs. 25,032.81) and medium size farm (Rs. 20,239.52 and Rs. 27,802.22) respectively. Cost $\mathrm{C}_{3}$ known as total cost per hectare accounted for Rs. 27,536.09, 30582.44 and 32,837.34 small, medium and large size groups respectively.
On the basis of foregoing discussion the major component of cost $\mathrm{C}_{3}$ (total), operational cost known as $\mathrm{A}_{1} \mathrm{~A}_{2}$ and Cost $\mathrm{B}_{1}$, $B_{2} \& C_{2}$ maximum in large farm followed by medium and small respectively.

Table showed that the productivity of urdbean in term of yield per hectare was observed in small size group $(7.54 \mathrm{q} / \mathrm{ha})$ followed by $7.09 \mathrm{q} /$ ha and $7.22 \mathrm{q} /$ ha in medium and large size farm respectively. Gross income a sum of yield multiplied by unit price of urdbean had also denoted in the same 
pattern as followed in productivity. In small size group the obtained gross income was Rs. 46,780.57, medium size group the obtained gross income was Rs. 45,376.23 and in large size category it was Rs 46,263.39.

On the basis of various costs as observed in input wise cost, net return per hectare recorded in the order of Rs. 21,747.76 for small size, Rs.17, 574.011 in medium size and Rs16, 411.26 in large size. The benefit cost ratio was highest in the case of small size group 1:1.86 (maximum) followed by $1: 1.63$ in medium and 1:1.54 (minimum) in large size group.

On the basis of above discussion it may be concluded that net return over cost $A_{1} / A_{2}$ and net return on cost $\mathrm{C}_{3}$ was comparatively higher in small size farm. The additional bonus point gone in the favours of small size group was higher benefit cost ratio in small size farm indicate that in spite of financial crisis and other constraints this category of farm organized and managed its farm operation effectively compared to medium and large size farms in the cultivation of urdbean crop. Involvement of higher human labour in this category indicates that under the situation of zero opportunity cost of family labour was appreciably utilized in this category with this intension that in cash payment term it required nothing except food and shelter which was a fixed liability of urdbean growers.

The list of results obtained from the research study concludes that the investment on human labour followed by manure and fertilizer is higher therefore to minimize the cost of cultivation of urdbean crop in small size farm cost involved on human labour use to be decreased but this avenue is opened for larger size farms. The operational cost $\mathrm{A}_{1} / \mathrm{A}_{2}$, and cost $\mathrm{B}_{1}, \mathrm{~B}_{2}$ and cost $\mathrm{C}_{1}, \mathrm{C}_{2} \& \mathrm{C}_{3}$ was comparatively higher in large size farm. The gross return a sum of output, into unit price also followed the same pattern as observed in the urdbean productivity. The net return over cost $\mathrm{C}_{3}$ (total cost) observed higher in large size followed by medium and small size farm in urdbean. Family labour income was higher in small size group which tends to decline as per increase of farm size. The net return per farm was higher in small size group due to higher allocation of urdbean area and tends to decline as per increase of size farm. Per hectare higher returns of urdbean as well as higher return ratio over per rupee invested cost shows better prospect for area expansion and production of urdbean cultivation.

\section{References}

1. Asmatoddin M, Jawale SV, Ghulghule JN and Tawale JB. 2009. Resource productivity and resource use efficiency in pulses production on medium farm in Marathwada. International Journal of Agricultural Sciences. 5(2): 359-362.

2. Brahmaprakash GP, Chandraprakash J, Ganeshaiah KN and Shaanker RU. 2004. Pulse yields: feeling the pulse. Current Science. 87(7): 859-861.

3. Burman RR, Singh, SK, Lakhan Singh and Singh, AK. 2008. Extension strategies for increasing pulses production for evergreen revolution. Indian Research Journal of Extension Education. 8(1): 5-8.

4. Reang D, Singha P, Thapa A, Rai B, Sarkar N and Nath, P.S. 2017. Evaluation of Mungbean (Vigna radiata L.) Cultivars for Resistance to Yellow Mosaic Virus. Int.J.Curr.Microbiol.App.Sci. 6(4): 8898.

5. Dhindsa KS and Sharma A. 1997. A regional analysis of growth and supply responses of pulses - a study of Punjab. Indian Journal of Agricultural Economics. 52(1): 87-100. 
6. Gent GP. 1994. Policy incentives for expanding European pulse production. Expanding the production and use of cool season food legumes. Proceedings of the Second International Food Legume Research Conference on pea, lentil, faba bean, chickpea, and grasspea, Cairo, Egypt. 361-366.

7. Gowdha Laxmipati, C.L., Charturvedi, S.K., Gour, P.M., Sameer Kumar, C.V. and Jukanti, A.K. (2015). Pulse research and development strategies for India. Pulse Handbook (2015).

8. Gupta SK. 2001.Economics of pulses production and identification of constraints in raising their production (a consolidated report of AERC studies). Ad-hoc Study-Agro-Economic Research Centre for Madhya Pradesh, Jawaharlal Nehru Krishi Vishwa Vidyalaya. 79, 177.

9. Hasan MK, Miah MA M and Rahman MM. 2008. Influence of environmental and managerial factors on efficiency of improved pulses production in Bangladesh. Asia-Pacific Journal of Rural Development. 18(1): 123-136.

10. Pathak AR, Pithia MS, Javia RM and Mehta DR. 2017. Challenges and options for meeting the needs of pulses-A review. Arc Journals. Vol. 38(2), pp. 103-111.

11. Patidar, M, and Sharma, H.2017. Correlation and path coefficient studies in Blackgram (Vigna mungo (L.) Hepper) on the growth of lowland rice. Journal of Pharmacognosy and Phytochemistry. 2017; 6(4): 1626-1628.

12. Rahman, Niaz Md. Farhat., Rahman's , Md. Mijanur., and Baten , Md Azizul. 2013. Modeling for Growth and Forecasting of Pulse Production in Bangladesh. Research Journal of Applied Sciences, Engineering, and Technology, 5(24):5578-5587.

\section{How to cite this article:}

Ghanshyam Patel, A. Shrivastava and Reena Sahu. 2020. Costs and Profitability of Urdbean on Sample farms. Int.J.Curr.Microbiol.App.Sci. 9(01): 2359-2368.

doi: https://doi.org/10.20546/ijcmas.2020.901.269 